\title{
What Did The Bonobo Say To The ATheist?
}

\author{
Steven R. Bowman \\ Humboldt State University, Psychology Department, Arcata, CA, USA. \\ sb2528@humboldt.edu
}

A Review of the Book

\section{The Bonobo and the Atheist}

By Frans de Waal. 2013.

W. W. Norton \& Company, New York City, USA, 243 pages. ISBN 978-0393073775 (Hardback, US\$27.95)

For centuries, theologists and philosophers have argued about the origins of things like empathy and morality. From the theological perspective, many argue that all of our moral "goodness" stems directly from commandments given by our favorite deity or deities; as the case may be. The of the rhetoric falls along the lines of a highly contested quote by Dostoevsky, which states "If god is dead, then everything is permissible." Whether or not he said those words exactly is still under debate, but the implication is that without spiritual guidance, humans will tend towards bad, selfish behavior and away from empathy, altruism, and compassion. de Waal dubbed this ideology Veneer Theory - the idea that human kindness and morality are a thin covering over the rotten insides of human nature. But perhaps there are things these theologians are not aware of. Perhaps they do not know of remarkable, recorded accounts like the one about a blind elephant being lead around to food and water, protected, and cared for by her herd. To my knowledge there is no account of elephants knowing anything about religion, yet they still seem to display the basic elements of empathy, sympathy, and compassion. While religious philosophers, apologists, and academics contend that these traits are uniquely human, de Waal and the bonobo would argue that the opposite may be true; that empathy and compassion arose out of a need for survival, which shaped our DNA along the way. de Waal also pokes fun at the sometimes furious and ridiculous rivalry between atheism and religion, and each group's incessant, counter-productive need to refute or disprove the other.

Throughout the book, de Waal offers several convincing arguments against morality's intrinsic dependence upon religion. Aside from the blind elephant anecdote, 
there are several accounts of empathy in many different species. I was astonished to learn that a rat when given a choice between a chocolate and the chance to free a rat that is caged in a plastic box will often elect to free his compatriot from captivity. I learned that macaques, when given a choice between pushing a button that reward only themselves with a treat or a button that rewards them and a visible companion, will often make the prosocial choice and elect to share their reward. These are just some of the accounts of "common decency" that occur in nature, but the meat of the argument for de Waal comes from observations of some of our closest primate relatives as well as others that may not be so close. His focus is mainly on the bonobo and the chimpanzee. He vividly describes the differences and similarities in how bonobos and chimps engage in social conduct and rules that sustain group cohesion, reduce group stress, and keep the peace which seems to be regarded by both species as essential to group survival. His stories paint a picture of nonhuman, primate societies that have their own customs, culture, and even a few quirks.

Sex therapist Susan Block (mentioned in the book) has often sung the praises of the promiscuous nature and sexual liberty that is inherent in bonobo culture. While this idea maybe somewhat appealing to those that favor making love over war, such a description would be somewhat misleading. Bonobo troops are based on a matriarchal hierarchy. Dominant females are the leaders of the group. Males rise in rank through the promotion and approval of the alpha females. As de Waal describes them, they are "momma's boys." While they may engage in behavior that humans might consider sexually risqué, bonobos are not the sex-crazed hedonists some make them out to be. The author quickly defended bonobos. Like a lawyer carefully building a case, de Waal comprehensively argues that what they do and why they do it appears to serve a greater purpose; facilitating group cohesion and keeping everyone happy. These behaviors are believed to be a mechanism used by bonobos to reduce stress during group conflicts and interactions with other groups, but usually fall short of actual mating. Genital rubbing, and various forms of mounting behavior help alleviate stress when meeting strangers and sex is often used to calm the individuals that display discontent. There are often displays of what humans describe as sexual behavior, but the idea that bonobos are overly sexual is erroneous because as de Waal points out, a juvenile male wishing to copulate with a female still requires the absence of dominant males and a willing participant.

Conversely, chimp behavior more closely mirrors human behavior with regards to social hierarchy such that it is more aggressive and patriarchal in nature. Alpha males are aggressive and dominant. Conflicts within and between chimpanzee troops can be nasty, or even fatal. But chimpanzees are not brutal savages. Alpha males will often use displays of strength and dominance to settle disputes between other group members when problems arise. They help to keep the peace. Even the most dominant male will beg for food from a lower ranking member of the troop rather than steal it. But why would the big guy beg from the little guy? Is it empathy? Is it a sense of fairness? Is it just to keep the peace? de Waal suggests it's all three. He explains this position by elaborating on an experiment that involved giving treats to one female chimp in view of other chimps. At first, she is overjoyed at the idea of a surplus of goodies all to herself. But suddenly, she realizes she's being watched by the other chimps. She becomes nervous and begins to refuse the treats. She gestures to the others. She does not accept anything else until the others have gotten a share. It would seem she could feel the dirty looks and didn't want to hear about it later. If that's not empathy, fairness, and a desire to keep the peace, what is? 
The Bonobo and the Atheist is refreshingly humorous and captivating look at life, religion, social groups, and evolution. de Waal references the work of artist Hieronymus Bosch in his reflections on the concept of human empathy. There are several inclusions of legendary primatologist Jane Goodall's work, which provide a rich background to the story. He even includes his meeting with the Dalai Lama. The book includes several scientific studies, experiments, and observations from de Waal's experiences working with nonhuman primates. His stories explain and expand on the evolutionary nature of empathy and other prosocial behaviors that have helped species survive and flourish. One of the book's greatest strength is its ability to cast doubt on the idea of moral superiority in our species. It points out in fact, that we homo sapien sapiens are just another species that may have simply taken a few too many steps away from our more cooperative ancestors. I struggled to find a weakness in this work, as any good critic should, but ultimately failed. I really like this book.

The Bonobo and the Atheist is an enlightened examination of the ethical heuristics that guide and help sustain the survival of a variety of social animals that are not privy to the lofty notions of gods, philosophy, or religion. It is a powerful demonstration of empathy as a group survival mechanism that has shaped culture, society, behavior, and DNA across species. The book is filled with colorful descriptions of art, philosophy, and scientific research that does not require one to be an expert to understand. His reflections on Bosch's works allows even those of us who can't draw stick figures to save our lives to understand what the artist might have meant beyond the sentiment that hell is a bad place. His references to Goodall's work include amazing stories of a lost, interactive method of research that current ethical practices no longer allow, and for good reason. Inclusions of Goodall's work might even invoke warm memories of watching Jane and the chimps on public television as a child for nature fans. Finally, de Waal calls for peace between the warring factions of science and religion by pointing to the futile and impossible challenge of one side trying to disprove the other. He believes finding common ground is a far more effective tool for resolving philosophical and religious differences. It's advice that both religious and scientific determinists should take to heart. What did the bonobo say to the atheist? If bonobos could talk to us, they might say many things. They might say that maybe we should let females run things if we want a more relaxed society. They might ask us to be fair to each other. They might say that sex is good for easing tensions and keeping the peace. Bonobos may have a lot to teach us about empathy, compassion, and morality. If a little more physical affection makes for a better society, who are we to argue if everyone is willing?

\section{ABOUT THE AUTHOR}

Steven Bowman is a graduate student in the Behavioral Endocrinology Research Lab at Humboldt State University. He is interested in social neuroendocrinology, primatology, and the effects of hormones on social behavior and attitudes. He is also interested in the multidimensional gene editing model for treating schizophrenia using C.R.I.S.P.R. CAS-9, Immunocompetency/androgen/facial cues research, and investigating the behavioral impact of hyperthyroidism. He is a novice writer, guitarist, and works as caregiver for elderly veterans. He resides in Eureka, CA. 